\title{
Upper boundaries of the Pacific and Philippine Sea plates near the triple junction off the Boso Peninsula deduced from ocean-bottom seismic observations
}

\author{
Aki Ito ${ }^{*}$, Hiroko Sugioka ${ }^{2}$, Koichiro Obana $^{3}$, Ryota Hino ${ }^{4}$, Daisuke Suetsugu ${ }^{1}$, Kazuo Nakahigashi ${ }^{5}$, \\ Masanao Shinohara ${ }^{6}$, Masaru Nakano ${ }^{3}$ and Yojiro Yamamoto ${ }^{3}$
}

\begin{abstract}
We determined hypocenter distributions and focal mechanisms of earthquakes off the Boso Peninsula, Japan, based on seafloor observations using ocean-bottom seismometers (OBSs). From OBS data, we detected and located earthquakes that were closer to the trenches than had previously been reported. The determined focal depths of relocated hypocenters were systematically shallower than those in the Japan Meteorological Agency catalog determined from land-based data. The hypocenter distribution was separated into two groups: one associated with the Pacific plate (PAC) and the other with the North American and/or Philippine Sea plates (PHS). For the former group, both the focal depths and mechanisms of low-angle thrust-faulting earthquakes were consistent with the geometry of the PAC determined by previous studies. Among the latter group, we selected low-angle thrust-faulting earthquakes with a slip direction parallel to the direction of PHS subduction or with a dip direction parallel to the PHS to delineate the upper boundary of the PHS. The depth of the plate upper boundary off the Boso Peninsula was found to be approximately $6 \mathrm{~km}$ shallower than previously reported estimates.
\end{abstract}

Keywords: Boso Peninsula, Ocean-bottom seismometer, Philippine Sea plate, Pacific plate, Hypocenter distribution

\section{Background}

The region off the Boso Peninsula, Japan, is located near a trench-trench-trench triple junction (Fig. 1a); the Pacific plate (PAC) is subducted westward at the Japan Trench beneath the North American plate (NA) with a relative speed of $8.3 \mathrm{~cm} / \mathrm{a}$ (DeMets et al. 2010), and the Philippine Sea plate (PHS) is subducted northwestward beneath the NA at the Sagami Trough with a relative speed of $3.8 \mathrm{~cm} / \mathrm{a}$ (DeMets et al. 2010). The PHS overrides the PAC (e.g., Ishida 1992; Hori 2006), and its northeastern limit is determined based on small repeating earthquakes (Uchida et al. 2009), which occur at fairly

\footnotetext{
*Correspondence: iaki@jamstec.go.jp

${ }^{1}$ Department of Deep Earth Structure and Dynamics Research, Japan Agency of Marine-Earth Science and Technology, 2-15 Natsushima-cho, Yokosuka, Kanagawa 237-0061, Japan

Full list of author information is available at the end of the article
}

consistent locations along the upper boundary of the subducting slabs (e.g., Igarashi et al. 2003).

The region is characterized by various seismic and geodetic activities (Fig. 1a): The 1703 Genroku Kanto earthquake $(M=7.9-8.2)$ and the 1923 Kanto earthquake $\left(M_{\mathrm{w}}=7.9\right)$ were interplate events associated with the subduction of the PHS (e.g., Matsu'ura et al. 2007; Namegaya et al. 2011; Sato et al. 2016). Slow slip events occur with an average interval of 6 years near the rupture area of these interplate earthquakes (e.g., Ozawa et al. 2003; Sagiya 2004; Hirose et al. 2014). Significant increases in seismicity and Coulomb stress after the 2011 TohokuOki earthquake $(M=9)$ are also recognized in the region (Toda et al. 2011).

To understand these seismic and geodetic phenomena, it is important to accurately determine the geometry of the boundaries between the three plates, and the plate 


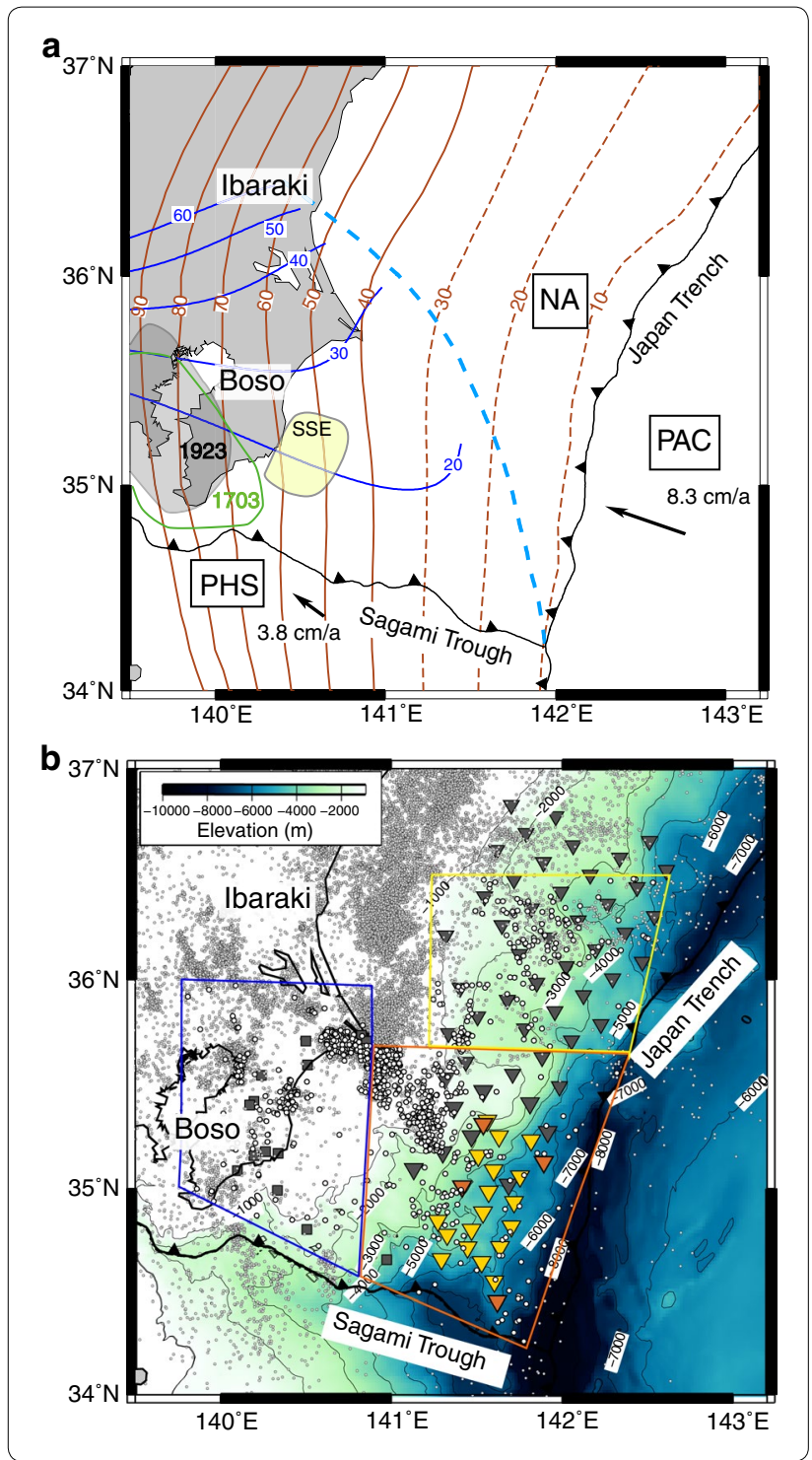

boundaries in the region off the Boso Peninsula have been studied extensively. Uchida et al. (2010) determined the upper boundary of the PHS by analyzing repeating earthquakes and seismic waves converted at the plate boundary. Their results showed that the upper boundary of the PHS is located at depths of $10-30 \mathrm{~km}$ beneath the Boso Peninsula. The upper boundary of the subducted PAC has been detected at depths greater than $40 \mathrm{~km}$ based on relocated hypocenter distributions (Nakajima and Hasegawa 2006; Nakajima et al. 2009). The upper boundary at shallower depths has not yet been well constrained, but has been estimated through interpolation from the location of the PAC upper boundary at a depth of $40 \mathrm{~km}$ and the trench axis. Because previous studies mainly used data from land-based stations alone, the shallow parts of the PAC-NA and PHS-NA boundaries
Fig. 1 Tectonic setting and bathymetric map of the study area. a Tectonic setting of the study area. Brown contours show depths of the upper boundaries of the Pacific plate (PAC) obtained by Nakajima and Hasegawa (2006) and Nakajima et al. (2009), with dashed contours estimated by interpolation. See text for details. Blue contours show the depth of the upper boundary of the Philippine Sea plate (PHS) estimated by Uchida et al. (2010). Blue dashed line denotes the NE limit of the PHS reported by Uchida et al. (2009). The source areas of the 1703 Genroku Kanto earthquake and the 1923 Kanto earthquake are indicated by gray and green lines, respectively (e.g., Matsu'ura et al. 2007; Sato et al. 2016). The area of slow slip events is shown in yellow (e.g., Ozawa et al. 2003; Sagiya 2004; Hirose et al. 2014). Black lines with triangles represent trench axes. Black arrows indicate the motion of the PAC and the PHS with respect to the North American plate (NA) (DeMets et al. 2010). b Bathymetric map showing the locations of stations used in this study, with orange and yellow triangles indicating deployed broadband ocean-bottom seismometers (BBOBSs) and short-period ocean-bottom seismometers (SPOBSs), respectively, and gray triangles and squares indicating OBSs of the Earthquake Research Institute (ERI) of the University of Tokyo and stations operated by the National Research Institute for Earth Science and Disaster Prevention, respectively. Small gray dots are epicenters derived by the Japan Meteorological Agency (JMA) during our observation period of March 2012 to March 2013. Earthquake selection areas are delineated by orange, yellow, and blue lines, and white dots are the epicenters determined by JMA that were analyzed in this study. See text for details

beneath the area offshore of the Boso Peninsula (particularly trenchward from $141^{\circ} \mathrm{E}$ ) have not yet been defined. Precise rendering of the plate boundaries, particularly at shallow depths, is also crucial for assessing the seismic and tsunami hazards of large interplate earthquakes. The 2011 Tohoku-Oki earthquake indicated that the shallowest part of the subducted Pacific slab has the potential for significant seismic slip (e.g., Yagi and Fukahata 2011; Satake et al. 2013).

Few seismic observations have been conducted with ocean-bottom seismometers (OBS) off the Boso Peninsula, particularly south of $35.5^{\circ} \mathrm{N}$. The Earthquake Research Institute (ERI) of the University of Tokyo conducted aftershock observations following the 2011 Tohoku-Oki earthquake across a broad area of the Japan Trench forearc region (Shinohara et al. 2011, 2012a), but they did not cover the majority of the region off the Boso Peninsula (south of $35.5^{\circ} \mathrm{N}$ ). In this study, we determine hypocenter distributions and focal mechanisms of earthquakes off the Boso Peninsula, as close to the Japan Trench and Sagami Trough as possible, by using data from both OBSs and land-based stations.

\section{Data}

We conducted seafloor observations with OBSs off the Boso Peninsula for 1 year from March 2012 to March 2013. The ocean-bottom instruments included six broadband ocean-bottom seismometers (BBOBSs) (Kanazawa et al. 2009; Shinohara et al. 2012b) and 23 short-period 
ocean-bottom seismometers (SPOBSs). We term the BBOBS and SPOBS that we deployed the "Japan Agency of Marine-Earth Science and Technology (JAMSTEC) OBSs." Seismic data recorded by four of six BBOBSs and 20 of 23 SPOBSs were successfully recovered in March 2013. Figure 1b shows the locations of stations used in this study. The JAMSTEC OBSs were installed on the seafloor at depths of 2000-6000 m with an average spacing of approximately $15 \mathrm{~km}$. Two of the BBOBSs were equipped with differential pressure gauges (DPGs) (Araki and Sugioka 2009). To cover the northern part of the Boso offshore area, we used seismic data from 50 OBSs of the ERI (Shinohara et al. 2011, 2012a) for the same period as the JAMSTEC OBSs were deployed. In addition to the OBS stations, we also used seismic data from 15 permanent land-based seismic stations on the Boso Peninsula operated by the National Research Institute for Earth Science and Disaster Prevention (NIED) (http://www.bosai. go.jp/e/index.html) (Okada et al. 2004). The specifications, observation periods, and locations of the stations are summarized in Fig. 1b and Table 1.

\section{Methods}

We analyzed approximately 1000 earthquakes between March 2012 and March 2013 from the Japan Meteorological Agency (JMA) catalog (Fig. 1b, https://hinetwww11. bosai.go.jp/auth/?LANG=en), with magnitudes ranging from 1.1 to 6.3. To select earthquakes, we delineated three regions (indicated by orange, yellow, and blue lines in Fig. 1b) where we expected the hypocenters to be well constrained by data from JAMSTEC and ERI OBSs, and land-based stations. Of the earthquakes in the JMA catalog located within these three regions, we selected those with signals that were recorded by at least three JAMSTEC OBS stations. We picked the onset times of P- and $\mathrm{S}$-wave arrivals manually from the vertical and horizontal components of the OBS data. We also recorded the polarity of P-wave first motions when possible. We used the DPG records of one BBOBS to obtain onset times and first motions in cases where velocity seismograms were not available. For the land-based stations, we collected $\mathrm{P}$ - and $\mathrm{S}$-wave arrival data and $\mathrm{P}$-wave first motion data from the catalog published by NIED. The total numbers of P- and S-wave arrivals used in this study were 23,670 and 12,872 , respectively.

We first determined hypocenters assuming a onedimensional model and the maximum-likelihood estimation technique of Hirata and Matsu'ura (1987) to examine differences between the JMA hypocenters from land-based station data and hypocenters derived from both OBS and land-based data. Using P- and S-wave onset times, we located earthquakes for which at least 10 data were available. We used P-wave velocity $\left(V_{\mathrm{p}}\right)$ structure in the JMA2001 model (Fig. 2a), which is the standard velocity model of the Japanese Islands (Ueno et al. 2002) and is used by JMA to locate earthquakes. S-wave velocity $\left(V_{\mathrm{s}}\right)$ was calculated using $V_{\mathrm{p}}$ and the $V_{\mathrm{p}} / V_{\mathrm{s}}$ ratio. Although $V_{\mathrm{p}} / V_{\mathrm{s}}$ ratios in the JMA2001 model change with depth, we adopted a constant $V_{\mathrm{p}} / V_{\mathrm{s}}$ ratio of 1.73 , which is the average ratio for depths shallower than $60 \mathrm{~km}$ in the JMA2001 model.

Tsuru et al. (2002) established the lateral variation of sedimentary layers along the Japan Trench forearc regions based on reflection studies; the thicknesses of sedimentary layers would also be expected to vary between the OBS sites. To account for the heterogeneity of sediment layers, we introduce a station correction term for earthquake location determination. We iteratively located earthquakes using the average difference between observed and calculated travel times $(\mathrm{O}-\mathrm{C}$ times) at each station as the station correction until the root-mean-squares (RMS) of the $\mathrm{O}-\mathrm{C}$ times converged.

Next, we estimated hypocenter locations using a simplified three-dimensional velocity model (Fig. 2b), applying the three-dimensional geometries of the subducted PAC obtained in previous studies (Nakajima and Hasegawa 2006; Nakajima et al. 2009) based on interplate earthquake distribution (Fig. 1a). The oceanic crust model for the PAC was constructed from the results of a previous refraction study along the Japan Trench (Ito et al. 2005). We assumed

Table 1 Specifications of the stations used in this study. Stations in italic were deployed for seafloor observation

\begin{tabular}{lllcr}
\hline Station & $\begin{array}{l}\text { Natural frequency } \\
\text { of sensor }(\mathbf{H z})\end{array}$ & $\begin{array}{l}\text { Sampling } \\
\text { frequency } \mathbf{( H z})\end{array}$ & $\begin{array}{l}\text { Number } \\
\text { of stations }\end{array}$ & Observation period \\
\hline BBOBS & 0.0228 & 200 & 4 & Mar. 2012-Mar. 2013 \\
SPOBS & 4.5 & 100 & 7 & Mar. 2012-Mar. 2013 \\
SPOBS & 4.5 & 100 & 10 & May 2012-Mar. 2013 \\
SPOBS & 4.5 & 100 & 3 & Dec. 2012-Mar. 2013 \\
ERI OBS & 1 & 200 & 15 & Oct. 2011-Aug. 2012 \\
ERI OBS & 1 & 200 & 35 & Apr.-Nov. 2012 \\
NIED (Hi-net) & $1,3,5$ & 100 & 15 & \\
\hline
\end{tabular}



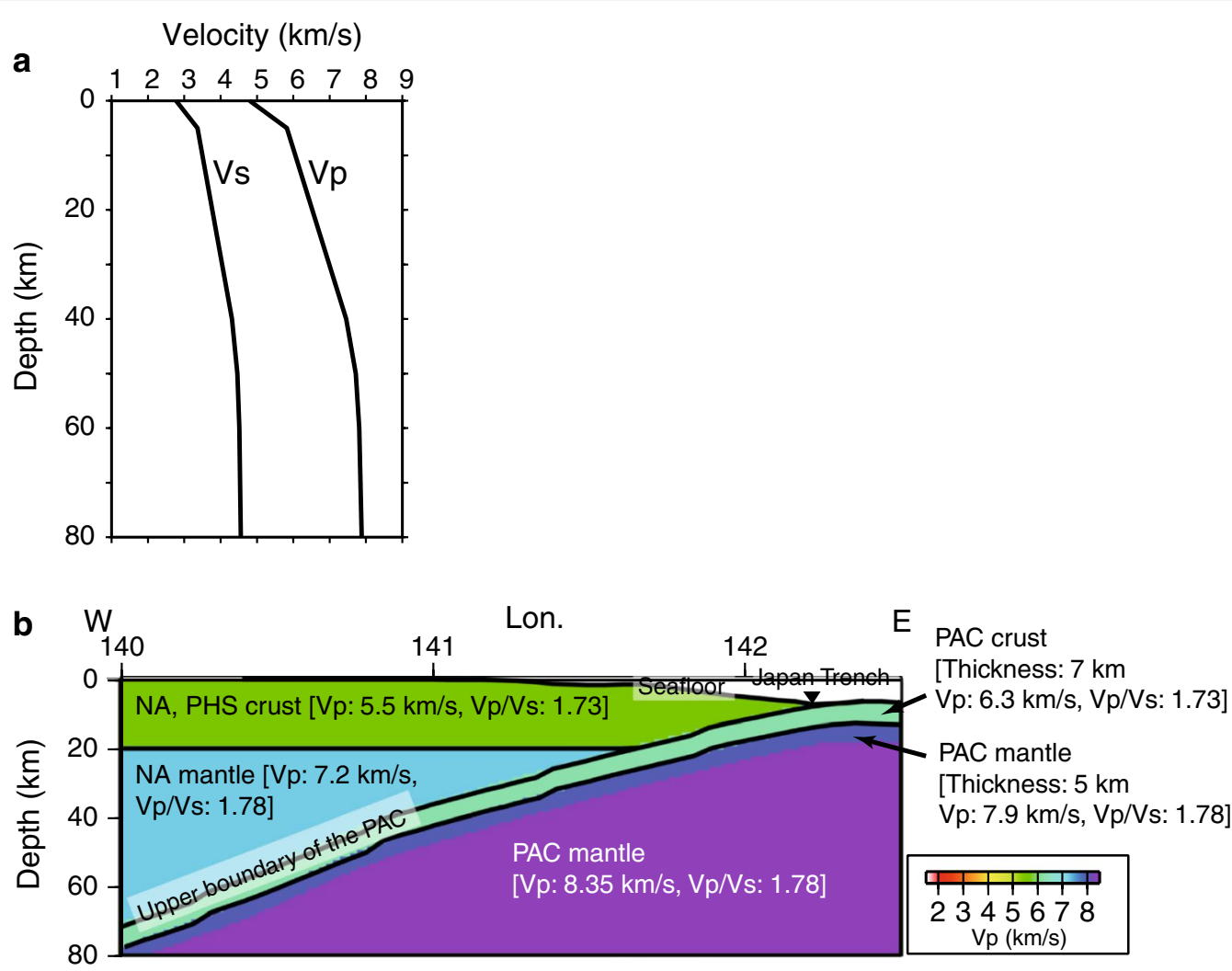

Fig. 2 Models for hypocenter determination. a One-dimensional velocity model JMA2001 (Ueno et al. 2002) used for hypocenter determination. b Three-dimensional model used for hypocenter determination. The configuration of the upper boundary of the PAC was obtained from Nakajima and Hasegawa (2006) and Nakajima et al. (2009). The section is along $35.4^{\circ} \mathrm{N}$

a 5-km-thick layer of $V_{\mathrm{p}}=7.9 \mathrm{~km} / \mathrm{s}$ just below the oceanic crust of the PAC (Ito et al. 2005). For the deeper part of the PAC mantle, we assumed a $V_{\mathrm{p}}$ of $8.35 \mathrm{~km} / \mathrm{s}$ based on results of tomographic study near the Boso Peninsula (Nakajima et al. 2009). The overlying crust and mantle consist of the NA and PHS plates, and we assumed crustal $V_{\mathrm{p}}$ to be $5.5 \mathrm{~km} / \mathrm{s}$, which is an average velocity above the Moho based on results of a refraction study off the Boso Peninsula (Nakahigashi et al. 2012). The boundary between the crust and mantle was assumed to remain at a constant depth of $20 \mathrm{~km}$, as described by Nakahigashi et al. (2012). A tomographic study from Nakajima et al. (2009) was used to derive the NA mantle $V_{\mathrm{p}}$ of $7.2 \mathrm{~km} / \mathrm{s}$. To construct the $\mathrm{S}$-wave velocity model, we assumed a $V_{\mathrm{p}} / V_{\mathrm{s}}$ ratio of 1.73 in the crust and 1.78 in the mantle based on the studies of Nakajima et al. (2009) and Hino et al. (2009).

We used NonLinLoc software (Lomax et al. 2000) based on a grid-search algorithm for hypocenter determination with a three-dimensional model. The grid node spacing of the velocity model was assumed to be $1 \mathrm{~km}$. We introduced site correction values calculated from average $\mathrm{O}-\mathrm{C}$ times in the same manner as that used for hypocenter determination with the one-dimensional velocity model.
After the hypocenters were located, we determined focal mechanisms based on P-wave polarity data using the FOCMEC software (Snoke 2003) for earthquakes with at least seven available polarity data.

\section{Results}

Using the JMA2001 model, we located 720 earthquakes with errors of less than $5 \mathrm{~km}$ in both the horizontal and depth directions and with the RMS of travel time residuals below $1 \mathrm{~s}$ (Fig. 3a). The average errors in epicenter locations and depths were 1.08 and $1.68 \mathrm{~km}$, respectively. The RMS of travel time residuals for P-wave and $\mathrm{S}$-wave arrival times were 0.44 and $0.83 \mathrm{~s}$, respectively. We present the station corrections (average $\mathrm{O}-\mathrm{C}$ time at each station) in Additional file 1: Figures A1a and A1b. In Fig. 3a, we compare the hypocenters to those determined by JMA. West of $141.5^{\circ} \mathrm{E}$, the newly reported epicenter positions differ from those of the JMA by several kilometers, but they differ by more than $10 \mathrm{~km}$ east of $141.5^{\circ} \mathrm{E}$. Focal depths determined by JMA are largely scattered between depths of $20-80 \mathrm{~km}$ east of $141.5^{\circ} \mathrm{E}$, while hypocenters derived from OBS data are located within depths of $0-40 \mathrm{~km}$. Previous seismic observations 
along the Japan Trench forearc region show that hypocenters relocated using OBS data tend to be shallower than those determined using only land-based station data (e.g., Shinohara et al. 2012a), and that is also the case in this study. The earthquakes with depths of $40-60 \mathrm{~km}$ that are clustered around $140.6^{\circ} \mathrm{E}$ are exceptionally deep relative to those determined by JMA. Seismic signals from the hypocenters of deep earthquakes to offshore OBSs pass through the PAC slab with higher velocities than in the JMA2001 model. Without including the high velocity slab in travel time calculations, the hypocenters would need to be located systematically deeper than the actual focal depths to explain the observed larger apparent velocities at OBSs.

Figure $3 \mathrm{~b}$ shows the hypocenter distribution based on the three-dimensional velocity model, which is less scattered and more compact than that based on the onedimensional velocity model. We located 881 earthquakes with an error of less than $2 \mathrm{~km}$ in the horizontal direction and less than $3 \mathrm{~km}$ in the depth direction and an RMS of the travel time residual below $1 \mathrm{~s}$. The average errors in epicenters and focal depths were 0.70 and $0.75 \mathrm{~km}$, respectively. The RMS of travel time residuals for P-wave and S-wave arrival times were 0.33 and $0.73 \mathrm{~s}$, respectively. Because the RMS of travel time residuals based on the three-dimensional model are smaller than those based on the JMA2001 model, we used hypocenter locations derived from the three-dimensional model in further analysis.

From Fig. 3b, we defined two earthquake groups: the shallow group and the PAC group. The shallow group had focal depths more than $7 \mathrm{~km}$ above the upper boundary of the PAC, and the PAC group had focal depths within $7 \mathrm{~km}$ of the upper boundary. The hypocenters of the PAC group are not distributed uniformly along the boundary in the studied region; most of the earthquakes located deeper than $30 \mathrm{~km}$ were concentrated around $35.5^{\circ} \mathrm{N}$, as shown in the $\mathrm{N}-\mathrm{S}$ vertical section. These patterns of hypocenter distribution are persistent throughout the two observation periods (Figs. 4 and 5), indicating that there are no systematic differences due to change of station distribution, with or without ERI OBS stations. In Fig. $3 \mathrm{~b}$, some of the earthquakes that belong to the PAC group appear to overlap with the shallow group. This phenomenon is an artifact related to the projection, because the hypocenters of the PAC group, which were selected based on depth intervals from the curved PAC upper boundary, are projected onto vertical sections. We present the station corrections (average $\mathrm{O}-\mathrm{C}$ time at each station) in Additional file 1: Figures A1c and A1d. Relatively large positive station corrections are seen at the JAMSTEC OBS stations near the triple junction, which indicate the presence of low-velocity anomalies below the stations. Thick sedimentary layers, revealed in a previous refraction study (Hirata et al. 1992) conducted near the JAMSTEC OBS stations with positive corrections, may be responsible.

We obtained focal mechanism solutions for 219 of 881 earthquakes based on the three-dimensional model. According to the JMA catalog, the magnitudes of these earthquakes range from 2.0 to 6.3. These earthquakes have errors in epicenter and focal depth location of less than $1.3 \mathrm{~km}$ and less than $2.2 \mathrm{~km}$, respectively. We selected mechanism solutions with less than or equal to three inconsistent polarity data. The number of inconsistent data was $\leq 1$ for 159 of the 219 total solutions. For the solutions with two or three inconsistent polarity data, the inconsistent data accounted for $12 \%$ of the total, on average. We provide examples of the focal mechanisms with the distribution of polarity data in Additional file 2: Figure A2. Because the coverage of the polarity data on the focal sphere is generally good, the focal mechanisms determined in the present study are considered to be robust. We also show the frequency distributions of azimuthal coverage and take-off angle coverage in Additional file 3: Figure A3. Azimuthal coverage ranged from $171.4^{\circ}$ to $358.3^{\circ}$, and take-off angle coverage ranged from $9.3^{\circ}$ to $77.2^{\circ}$.

Following the criteria of Frohlich (1992), the focal mechanisms of 100 earthquakes were classified as normal faulting, 77 as reverse faulting, and 29 as strike-slip faulting. We plotted the distributions of these focal mechanisms for the shallow and PAC groups in Figs. 4 and 5, respectively, along with a vertical section parallel to the PAC subduction direction. Only the focal mechanisms of earthquakes with magnitudes greater than 2.3 are plotted in the figures, to enhance their visibility, but the same pattern is shown when earthquakes with magnitudes between 2.0 and 2.3 are included.

For the shallow group, more than half of the focal mechanisms were normal faulting. Normal and strikeslip faulting earthquakes are distributed throughout the NA crust, whereas reverse-faulting earthquakes typically occur only at depths greater than $10 \mathrm{~km}$. Most reversefaulting earthquakes are located east of $141^{\circ}$. The PAC group is dominated by reverse faulting and shows fewer normal and strike-slip faulting earthquakes. Reversefaulting earthquakes are also detected close to the trench-trench-trench triple junction.

\section{Discussion}

\section{Comparison of hypocenter distribution and crustal structure}

We compare the hypocenter distribution and focal mechanisms of the present study to the $V_{\mathrm{p}}$ structure 


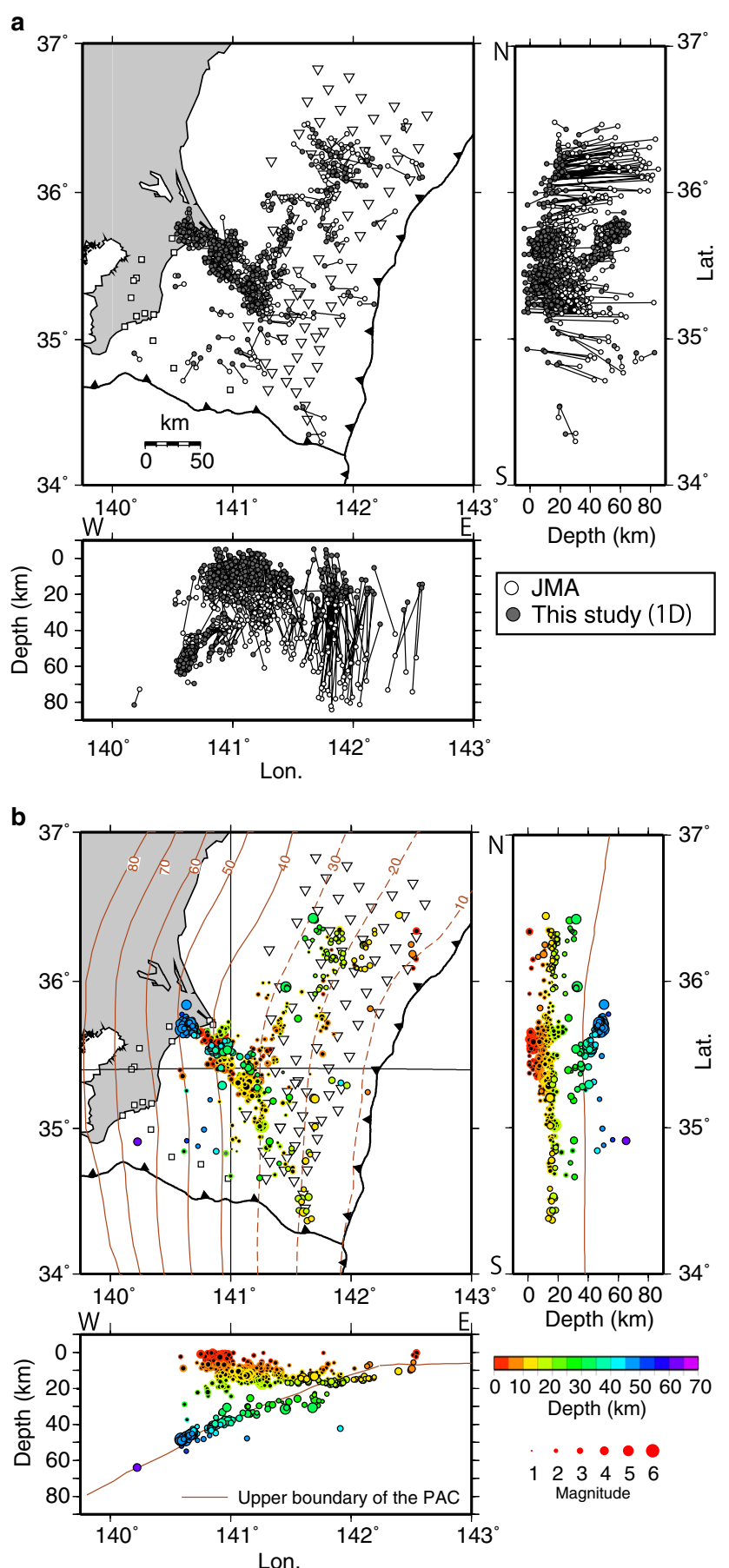

Fig. 3 Hypocenter location results. a A comparison of hypocenters relocated using the one-dimensional model shown in Fig. 2a with those determined from the JMA land-based seismic network data. Gray and white dots are the hypocenters determined in this study and by JMA, respectively, with identical earthquakes connected by black lines. The lower and right figures show E-W and N-S vertical sections, respectively. Triangles and squares indicate station locations. b Relocated hypocenters based on the three-dimensional model shown in Fig. 2b. Black dots surrounded by colors and colored dots surrounded by black represent the hypocenters of the shallow and PAC earthquake groups, respectively. Colors correspond to hypocenter depth. Brown contours show the upper boundaries of the PAC (Nakajima and Hasegawa 2006; Nakajima et al. 2009). The bottom and right panels show PAC upper boundaries along a latitude of $35.4^{\circ} \mathrm{N}$ and a longitude of $141^{\circ} \mathrm{E}$, respectively 
determined by the previous refraction survey along line $B-B^{\prime}$ (Nakahigashi et al. 2012) (Fig. 6b, c). Earthquakes that occurred within $20 \mathrm{~km}$ of the line are plotted. Few earthquakes were located in the sedimentary layers represented by the red and yellow layers. An absence of earthquakes in sedimentary layers along the Japan Trench forearc region has also been reported previously (e.g., Shinohara et al. 2012a; Obana et al. 2013).
Shallow group earthquakes were located within the NA crust (denoted by the green layer immediately beneath the yellow layer in Fig. $6 \mathrm{~b}$ ). South of $35.5^{\circ} \mathrm{N}$, the shallow group is distributed with its base at the NA-PHS boundary. Reverse-faulting earthquakes originated in a deeper part of the shallow group (Fig. 6c). North of $36^{\circ} \mathrm{N}$, most of the earthquakes occurred near the plate boundary between the NA and the PAC (Fig. 6b), and most were
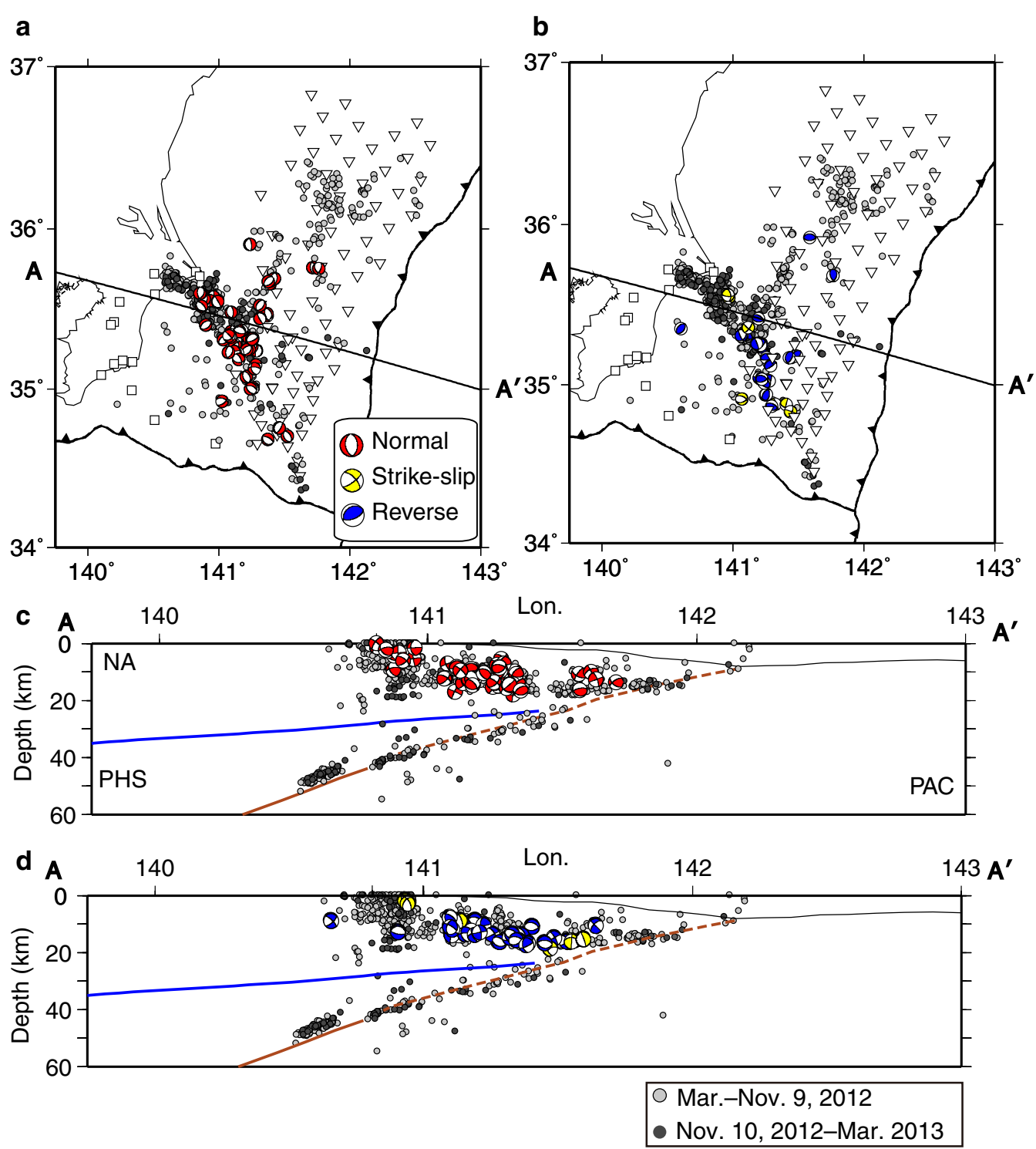

Fig. 4 Distribution of focal mechanisms for the shallow earthquake group with magnitudes greater than 2.3. Red, yellow, and blue beach balls correspond to normal, strike-slip, and reverse-faulting earthquakes, respectively. Focal mechanisms are in lower-hemisphere projections. Line $A-A^{\prime}$ defines the line projected onto the cross sections, parallel to the direction of PAC subduction. The blue and brown lines indicate the upper boundaries of the PHS (Uchida et al. 2010) and PAC (Nakajima and Hasegawa 2006; Nakajima et al. 2009), respectively. Light and dark gray dots show hypocenters based on the three-dimensional velocity model (Fig. 3b), with light gray dots corresponding to the period for which we could use ERI OBS seismic data, and the dark gray dots corresponding to the period for which we could not. Vertical cross sections have no vertical exaggeration. a, c Normal faults. b, d Strike-slip and reverse faults 


\section{a}

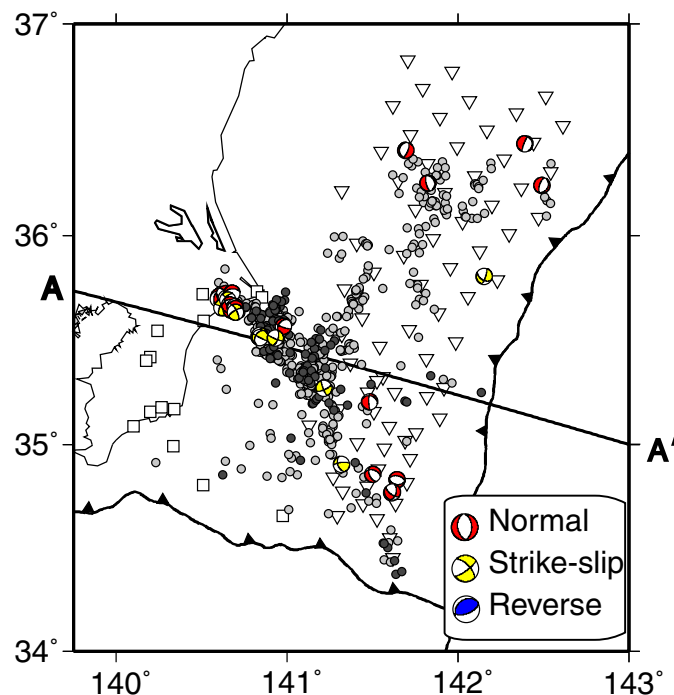

b

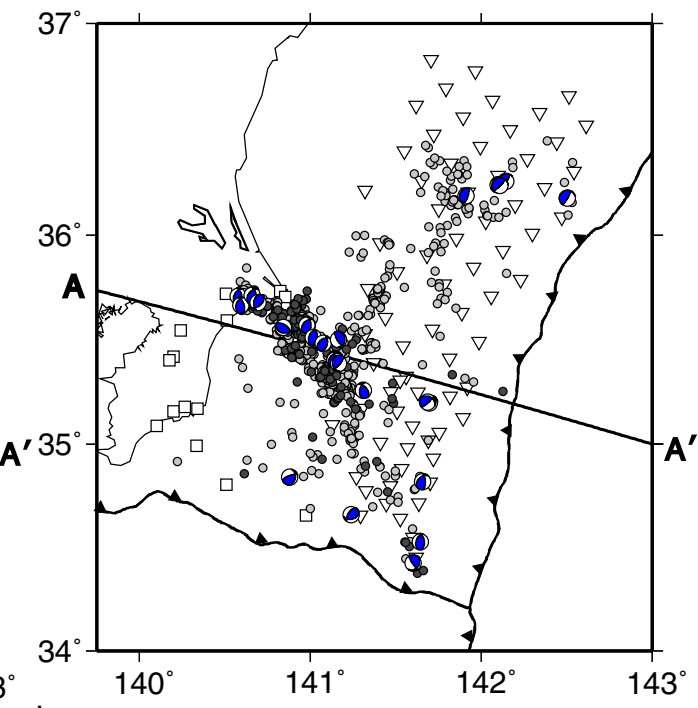

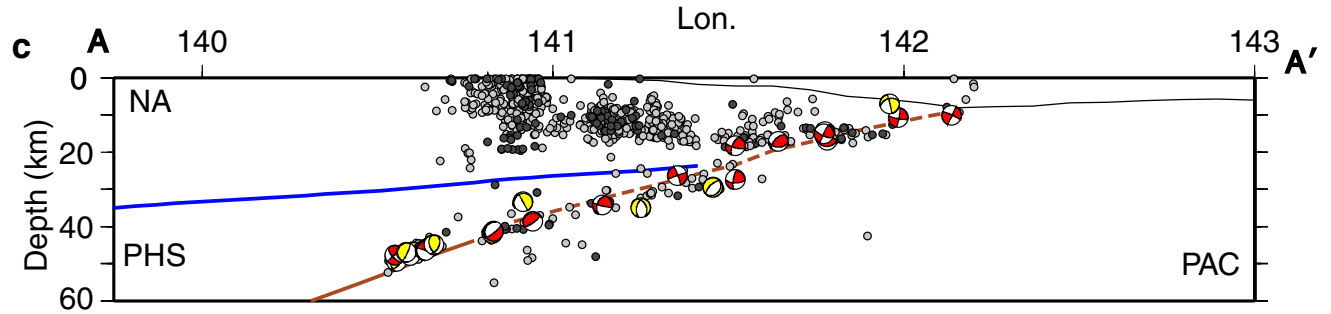

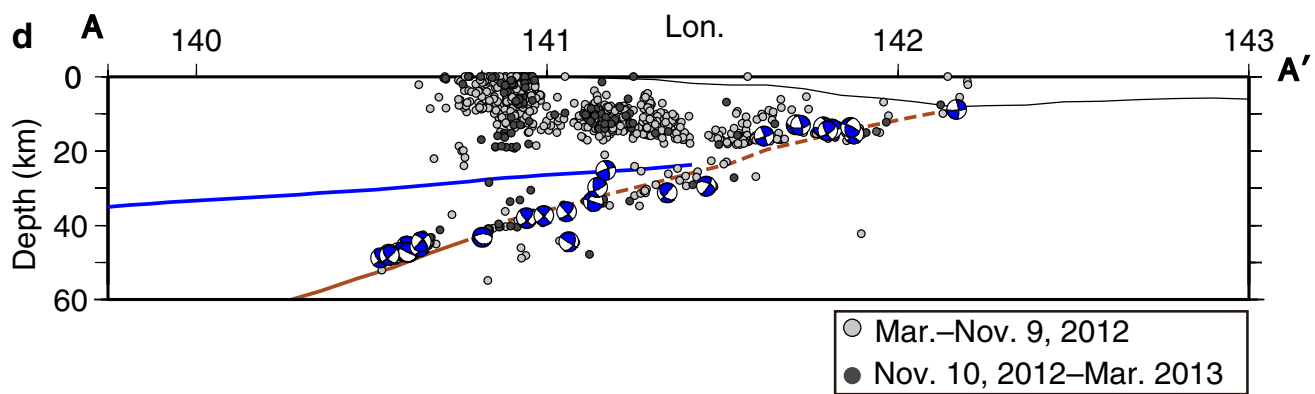

Fig. 5 Distribution of the focal mechanisms for earthquakes in the PAC group with magnitudes greater than 2.3. Symbols are as defined in Fig. 4. a, c Normal and strike-slip faults. b, d Reverse faults

reverse-faulting earthquakes (Fig. 6c). The hypocenter distribution and focal mechanisms identified in this study are thus consistent with the PHS-NA and PAC-NA boundaries determined by Nakahigashi et al. (2012).

\section{Upper boundary of the PAC}

Low-angle thrust-faulting earthquakes are often used to delineate the upper plate boundary of a subducted slab. In this study, we define low-angle thrust-faulting earthquakes as reverse-faulting earthquakes with a nodal plane dip angle below $35^{\circ}$. Figure 7 shows the distribution of 39 low-angle thrust-faulting earthquakes from the shallow group and the PAC group. Among the low-angle thrustfaulting earthquakes, one earthquake, labeled "RE" in Fig. 7, was identified by Uchida et al. (2016) as a repeating earthquake, which are commonly thought to occur along the upper boundaries of subducting slabs. We plotted two depth profiles of focal mechanisms parallel to the PAC subduction direction in Fig. 7b, c. Most earthquakes of the PAC group have nodal planes consistent with plate motion at the upper boundary of the PAC (DeMets et al. 2010).

The low-angle thrust-faulting earthquakes have hypocenters as shallow as $10-15 \mathrm{~km}$ in the off-Ibaraki region 


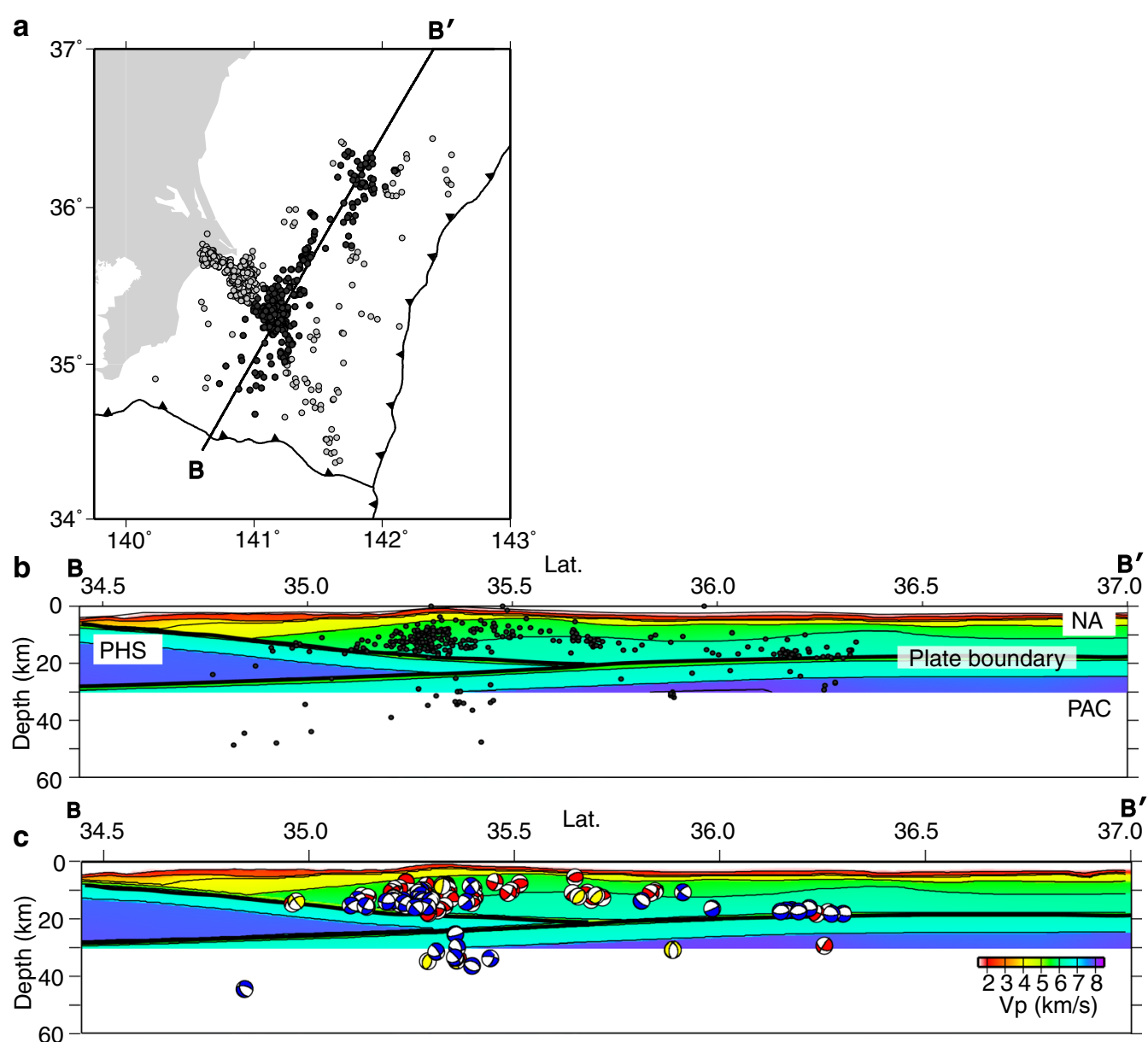

Fig. 6 Comparison of hypocenters $(\mathbf{a}, \mathbf{b})$ and focal mechanisms (c) of this study with a previous crustal model. Line $B-B^{\prime}$ shows the location of the refraction survey conducted by Nakahigashi et al. (2012), nearly perpendicular to the subduction direction of the PAC. Light gray dots show hypocenters based on the three-dimensional velocity model (Fig. 3b). Dark gray dots indicate the hypocenters of earthquakes within a 20-km-wide box on both sides of the $B-B^{\prime}$ profile

(north of $\left.36^{\circ} \mathrm{N}\right)$. Here, Shinohara et al. (2012a) identified interplate earthquake depths shallower than $40 \mathrm{~km}$ at the upper boundary of the PAC using seismic observations with OBSs. Mochizuki et al. (2008) determined the detailed configuration of the upper boundary of the PAC with refraction surveys along paths indicated by the yellow lines in Fig. 7a and estimated the depths of the upper boundaries of the PAC to be $8-15 \mathrm{~km}$. These depths are nearly consistent with the focal depths of the low-angle thrust-faulting earthquakes determined in this study (Fig. 7b). In addition, for the first time, we have located low-angle thrust-faulting earthquakes along the upper boundary of the PAC off the Boso Peninsula (south of $36^{\circ}$ ) to depths of up to $14 \mathrm{~km}$ (Fig. 7c). At depths greater than $40 \mathrm{~km}$, the focal depths of low-angle thrust-faulting earthquakes are consistent with the location of the upper boundary of the PAC determined by previous studies (Nakajima and Hasegawa 2006; Nakajima et al. 2009).

\section{The upper boundary of the PHS}

To locate the upper boundary of the PHS, we analyzed 16 low-angle thrust-faulting earthquakes determined from the shallow group. The focal mechanisms are plotted along profiles parallel to the PAC subduction direction (Fig. 7c) and parallel to the PHS subduction direction (Fig. 7d). Most were located near the bottom of the shallow group (see Figs. 4d, 7c). Eleven of the earthquakes had focal mechanisms with a slip direction parallel to the direction of PHS subduction (NW$\mathrm{SE}$ ), and one earthquake had a dip direction parallel to the PHS (N-S). Low-angle thrust-faulting earthquakes occur near the PHS-NA boundary identified by Nakahigashi et al. (2012), which is also plotted in Fig. 7c, d. If these earthquakes are assumed to represent slip along the upper boundary of the PHS, the boundary off the Boso Peninsula is approximately $6 \mathrm{~km}$ shallower than previously delineated (Uchida et al. 2010), in the 
a

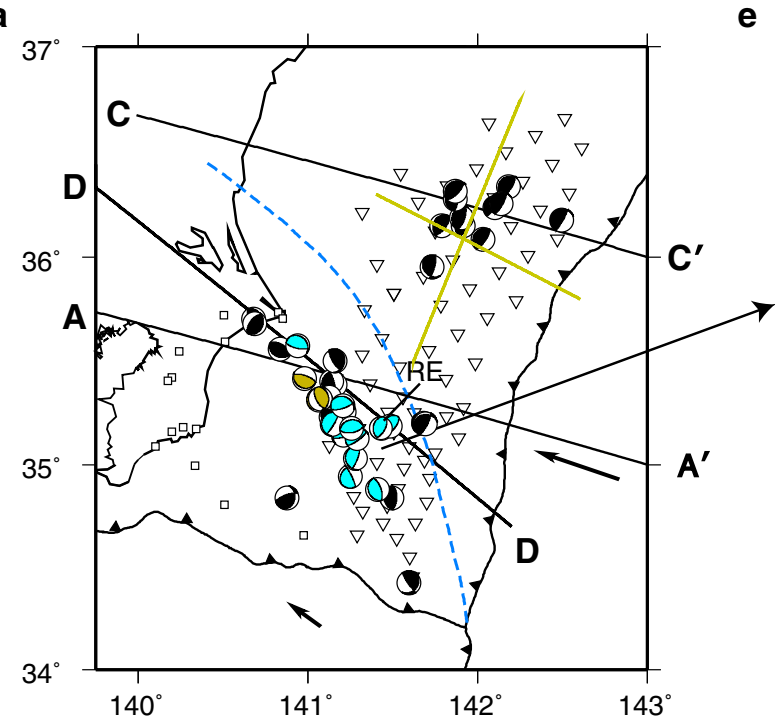

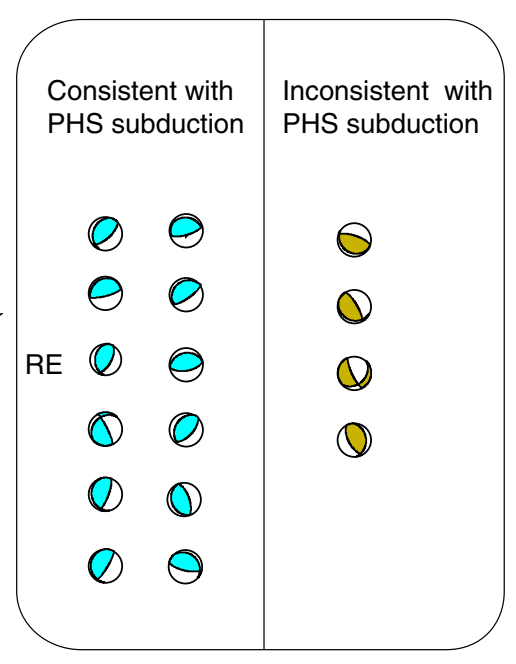

on.
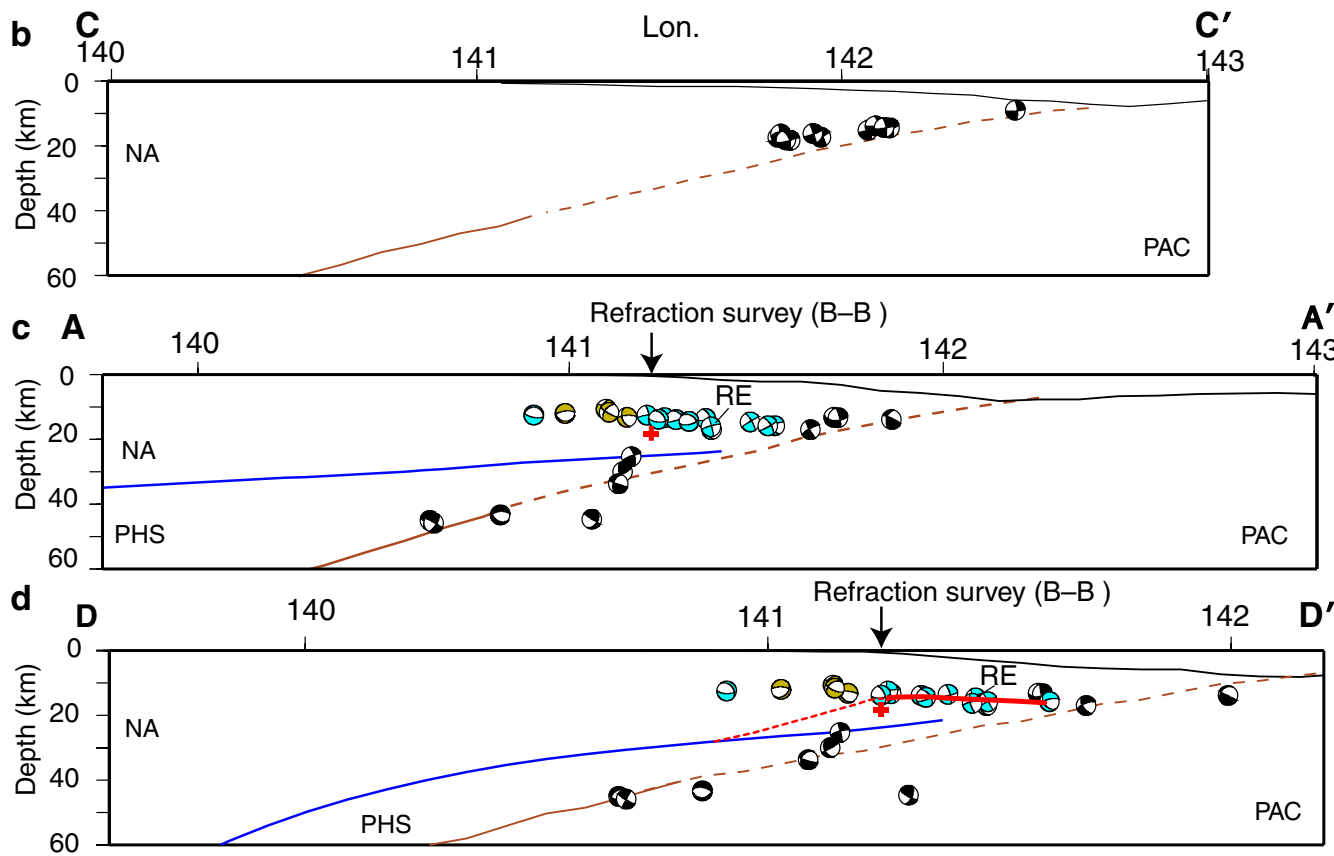

Fig. 7 Distribution of focal mechanisms of low-angle thrust-faulting earthquakes in $\mathbf{a}, \mathbf{b}, \mathbf{c}$ and $\mathbf{d}$. Black beach balls show PAC group earthquakes. Light blue and yellow-green beach balls show shallow group earthquakes, which are detailed in $\mathbf{e}$. Lines $C-C^{\prime}$ and $D-D^{\prime}$ define the projected line onto cross sections parallel to the subduction directions of the PAC and the PHS, respectively. Red crosses in $\mathbf{c}$ and $\mathbf{d}$ indicate the location of the PHS-NA boundary determined by Nakahigashi et al. (2012). Red lines in $\mathbf{d}$ show the connected upper boundary of the PHS in the trenchward and landward area

area between $34.8-35.5^{\circ} \mathrm{N}$ and $140.9-141.6^{\circ} \mathrm{E}$ (red solid curve in Fig. 7d). The shift of the PHS upper boundary arises mainly because the focal depths determined using OBS data were shallower than those derived from land-based data alone (Fig. 3). To connect the upper boundary of the PHS in the trenchward area determined in this study to that in the landward area identified by Uchida et al. (2010), the tip of the PHS must bend upward at longitudes around $140.9-141.3^{\circ} \mathrm{E}$ (red broken curve in Fig. 7d), which was also proposed by Uchida et al. (2010) based on their converted wave analysis.

\section{Focal mechanism}

We compared the focal mechanisms determined in this study with centroid moment tensor (CMT) solutions 
of 20 earthquakes for which both the CMT solutions and mechanism solutions (obtained in this study) were available (Additional file 4: Figure A4). The CMT solutions were determined through waveform inversion using F-net data (http://www.fnet.bosai.go.jp/top. php?LANG=en). The 20 earthquakes had magnitudes greater than 3.5, and the variance reductions of the waveform inversion were greater than $50 \%$. The average difference in the dip angle of focal mechanisms between the F-net data and the results of this study is $19.6^{\circ}$ with a standard deviation of $11.0^{\circ}$, and the average difference in strike angle is $28.0^{\circ}$ with a standard deviation of $30.5^{\circ}$. Considering the differences in data and methods (waveform inversion for the CMT solutions versus the $\mathrm{P}$-wave first motion method), we consider the focal mechanisms determined in this study to be consistent with the CMT solutions. Comparison of focal mechanisms for three of the 20 earthquakes with those reported in the Global CMT catalog (http:// www.globalcmt.org) (Dziewonski et al. 1981; Ekström et al. 2012) shows that the focal mechanisms given by the F-net, Global CMT, and this study are mutually consistent.

We have observed a significant number of normal and strike-slip faulting earthquakes (Figs. 4, 5), and most have T-axes in an almost E-W direction. In NA crust, significant enhancement of trench-normal extensional stress after the 2011 Tohoku-Oki earthquake was reported over a broad area in the forearc region by Hasegawa et al. (2012). The vigorous shallow seismicity with E-W extensional focal mechanisms we report here is consistent with the post-2011 seismic change. Asano et al. (2011) reported an increase of extensional seismicity within the subducting PAC slab near the large coseismic slip zone of the 2011 earthquake. The normal and strike-slip faulting events among the PAC group are interpreted as intraslab earthquakes, and their focal mechanisms suggest significant change of stress field off the Boso Peninsula, although the region is distant from the main rupture of the 2011 earthquake.

\section{Conclusions}

We conducted seafloor observations off the Boso Peninsula with OBSs for 1 year from March 2012 to March 2013 and determined hypocenter locations and focal mechanisms. We summarize the conclusions derived from these investigations as follows:

1. The focal depths of relocated hypocenters determined using OBS data are generally shallower than those determined by JMA in the study area.

2. Hypocenter distributions can be separated into two groups; one group is shallower than the upper boundaries of the PAC, and the other follows the upper boundary of the PAC.

3. Both the hypocenter distributions and the focal depths of low-angle thrust-faulting earthquakes are consistent with the NA-PAC and NA-PHS plate boundaries, which were determined by a previous refraction study off the Boso Peninsula (Nakahigashi et al. 2012).

4. Low-angle thrust-faulting earthquakes shallower than $40 \mathrm{~km}$ at the upper boundary of the PAC are detected for the first time in the off-Boso Peninsula region.

5. More than half of the low-angle thrust-faulting earthquakes in the shallow group have a slip direction parallel to the direction of PHS subduction. If these events are assumed to represent the upper boundary of the PHS, the depth of this boundary off the Boso Peninsula is approximately $6 \mathrm{~km}$ shallower than previously determined using only land-based data from the area between $34.8-35.5^{\circ} \mathrm{N}$ and $140.9-141.6^{\circ} \mathrm{E}$.

\section{Additional files}

Additional file 1: Figure A1. Distribution of average observed and calculated travel times ( $\mathrm{O}-\mathrm{C}$ times) used for station corrections in hypocenter locations; (a) and (b) are average $\mathrm{O}-\mathrm{C}$ times for $\mathrm{P}$ - and $\mathrm{S}$-waves, respectively, assuming a one-dimensional structure, whereas (c) and (d) are those assuming a three-dimensional structure. Circles with orange outer rims show broadband ocean-bottom seismometer (BBOBS) locations. The root-mean-squares (RMS) of station corrections for $\mathrm{P}$ - and $\mathrm{S}$-waves assuming a one-dimensional structure are $0.44 \mathrm{~s}(\mathrm{a})$ and $2.12 \mathrm{~s}(\mathrm{~b})$ respectively. The RMS of station corrections for $\mathrm{P}$ - and S-waves assuming a three-dimensional structure are $0.43 \mathrm{~s}$ (c) and $1.88 \mathrm{~s}(\mathrm{~d})$, respectively.

Additional file 2: Figure A2. Examples of focal mechanisms with the distribution of polarities (b) for hypocenters in (a). Event numbers are indicated by lower case letters a-l.

Additional file 3: Figure A3. Frequency distributions of azimuthal coverage and take-off angle coverage. Bar width is $10^{\circ}$. White and gray bars correspond to all faulting and low-angle thrust-faulting earthquakes, respectively.

Additional file 4: Figure A4. Comparison of earthquakes. (a) Hypocenter distributions. Black and gray dots indicate hypocenters reported in this study and by F-net, respectively. Identical earthquakes are connected with black lines. (b) Focal mechanisms in map view in lower-hemisphere projections. Beach balls correspond to F-net, this study, and Global CMT. Event numbers correspond to (a). (c) Focal mechanisms with the distribution of polarities. Event number corresponds to (a) and (b).

\section{Abbreviations}

OBS: ocean-bottom seismometer; PAC: Pacific plate; NA: North American plate; PHS: Philippine Sea plate; ERI: Earthquake Research Institute; BBOBS: broadband ocean-bottom seismometer; SPOBS: short-period ocean-bottom seismometer; JAMSTEC: Japan Agency of Marine-Earth Science and Technology; DPG: differential pressure gauge; NIED: National Research Institute for Earth Science and Disaster Prevention; JMA: Japan Meteorological Agency; O-C times: observed and calculated travel times; RMS: root-mean-square; CMT: centroid moment tensor; $V_{p}$ : $P$-wave velocity; $V_{s}$ : S-wave velocity. 


\section{Authors' contributions}

Al performed the BBOBS observations, data processing and analysis and wrote the manuscript. HS also performed the BBOBS observations, and KO performed the SPOBS observations. DS and RH suggested improvements of the manuscript. KN and MS provided support for the OBSs data collection by ERI. MN and YY supported the data processing and analysis. All authors read and approved the final manuscript.

\begin{abstract}
Author details
${ }^{1}$ Department of Deep Earth Structure and Dynamics Research, Japan Agency of Marine-Earth Science and Technology, 2-15 Natsushima-cho, Yokosuka, Kanagawa 237-0061, Japan. ${ }^{2}$ Department of Planetology, Graduate School of Science, Kobe University, 1-1 Rokkodai-cho, Nada-ku, Kobe, Hyogo 657-8501, Japan. ${ }^{3}$ Center for Earthquake and Tsunami, Japan Agency of Marine-Earth Science and Technology, 2-15 Natsushima-cho, Yokosuka, Kanagawa 237-0061, Japan. ${ }^{4}$ Research Center for Prediction of Earthquakes and Volcanic Eruptions, Graduate School of Science, Tohoku University, 6-6 Aza-Aoba, Aramaki, Aoba-ku, Sendai 980-8578, Japan. ${ }^{5}$ Tokyo University of Marine Science and Technology, 4-5-7, Konan, Minato-ku, Tokyo 108-8477, Japan. ${ }^{6}$ Earthquake Research Institute, University of Tokyo, 1-1-1, Yayoi, Bunkyo-ku, Tokyo 113-0032, Japan.
\end{abstract}

\section{Acknowledgements}

This study was partly supported by the Special Coordination Funds for the Promotion of Science and Technology (MEXT, Japan) designated as integrated research for the 2011 Tohoku Earthquake off the Pacific coast. We used data obtained from the Hi-net and F-net systems operated by NIED, and onshore observations obtained by JMA. Tsutomu Takahashi performed initial SPOBS data processing. We thank Naoki Uchida for providing a list of repeating earthquakes. The editor Junich Nakajima and an anonymous reviewer helped to greatly improve the manuscript.

\section{Competing interests}

The authors declare that they have no competing interests.

Received: 15 October 2016 Accepted: 20 January 2017

Published online: 09 February 2017

\section{References}

Araki E, Sugioka H (2009) Calibration of deep sea differential pressure gauge. JAMSTEC-R 9:141-148 (in Japanese with English abstract)

Asano Y, Saito T, Ito Y, Shiomi K, Hirose H, Matsumoto T, Aoi S, Hori S, Sekiguchi $S$ (2011) Spatial distribution and focal mechanisms of aftershocks of the 2011 off the Pacific coast of Tohoku Earthquake. Earth Planets Space 63:669-673. doi:10.5047/eps.2011.06.016

DeMets C, Gordon RG, Argus DF (2010) Geologically current plate motions. Geophys J Inter. doi:10.1111/j.1365-246X.2009.04491.x

Dziewonski AM, Chou TA, Woodhouse JH (1981) Determination of earthquake source parameters from waveform data for studies of global and regional seismicity. J Geophys Res 86:2825-2852. doi:10.1029/JB086iB04p02825

Ekström G, Nettles M, Dziewonski AM (2012) The global CMT project 2004-2010: centroid-moment tensors for 13,017 earthquakes. Phys Earth Planet Inter 200-201:1-9. doi:10.1016/j.pepi.2012.04.002

Frohlich C (1992) Triangle diagrams: ternary graphs to display similarity and diversity of earthquake focal mechanisms. Phys Earth Planet Inter 75:93-198

Hasegawa A, Yoshida K, Asano Y, Okada T, linuma T, Ito Y (2012) Change in stress field after the 2011 great Tohoku-Oki earthquake. Earth Planet Sci Lett 355-356:231-243. doi:10.1016/j.epsl.2012.08.042

Hino R, Azuma R, Ito Y, Yamamoto Y, Suzuki K, Tsushima H, Suzuki S, Miyashita M, Tomori T, Arizono M, Tange G (2009) Insight into complex rupturing of the immature bending normal fault in the outer slope of the Japan Trench from aftershocks of the 2005 Sanriku earthquake ( $M w=7.0$ ) located by ocean bottom seismometry. Geochem Geophys Geosyst 10:Q07018 doi:10.1029/2009GC002415

Hirata N, Matsu'ura M (1987) Maximum-likelihood estimation of hypocenter with origin time eliminated using nonlinear inversion technique. Phys Earth Plant Inter 47:50-61
Hirata N, Narumi T, Amishiki T, Katao H, Kaiho Y, Kashiwara S, Hino R, Baba H, Shiobara H, Koresawa S, Shinohara M, Kubo A, Kanazawa T, Kasahara J, Kinoshita H (1992) Report on DELP 1989 Cruise in the TTT junction areas Part 2: upper crustal structure near the trench-trench-trench triple junction off Boso Peninsula, Japan. Bull Earthq Res Inst Univ Tokyo 67:479-512

Hirose H, Matsuzawa T, Kimura T, Kimura H (2014) The Boso slow slip events in 2007 and 2011 as a driving process for the accompanying earthquake swarm. Geophys Res Lett 41:2778-2785. doi:10.1002/2014GL059791

Hori S (2006) Seismic activity associated with the subducting motion of the Philippine Sea plate beneath the Kanto district, Japan. Tectonophysics 417:85-100. doi:10.1016/j.tecto.2005.08.027

Igarashi T, Matsuzawa T, Hasegawa A (2003) Repeating earthquakes and interplate aseismic slip in the northeastern Japan subduction zone. J Geophys Res. doi:10.1029/2002JB001920

Ishida M (1992) Geometry and relative motion of the Philippine Sea plate and Pacific plate beneath the Kanto-Tokai district, Japan. J Geophys Res 97:489-513

Ito A, Fujie G, Miura S, Kodaira S, Kaneda Y, Hino R (2005) Bending of the subducting oceanic plate and its implication for rupture propagation of large interplate earthquakes off Miyagi, Japan, in the Japan Trench subduction zone. Geophys Res Lett 32:L05310. doi:10.1029/2004GL022307

Kanazawa T, Shinohara M, Shiobara H (2009) Recent progress in seafloor earthquake observations and instruments in Japan. Zisin 61:S55-S68 (in Japanese with English abstract)

Lomax A, Virieux J, Volant P, Berge C (2000) Probabilistic earthquake location in $3 \mathrm{D}$ and layered models: Introduction of a Metropolis-Gibbs method and comparison with linear locations. In: Thurber $\mathrm{CH}$, Rabinowitz N (eds) Advances in seismic event location. Kluwer, Amsterdam, pp 101-134

Matsu'ura M, Noda A, Fukahata Y (2007) Geodetic data inversion based on Bayesian formulation with direct and indirect prior information. Geophys J Int 171(3):1342-1351

Mochizuki K, Yamada T, Shinohara M, Yamanaka Y, Kanazawa T (2008) Weak Interpolate coupling by seamounts and repeating M7 earthquakes. Science 321:1194-1197

Nakahigashi K, Shinohara M, Mochizuki K, Yamada T, Hino R, Sato T, Uehira K, Ito Y, Murai Y, Kanazawa T (2012) P-wave velocity structure in the southernmost source region of the 2011 Tohoku earthquakes, off the Boso Peninsula deduced by an ocean bottom seismographic survey. Earth Planets Space 64:1149-1156. doi:10.5047/eps2012.06.006

Nakajima J, Hasegawa A (2006) Anomalous low-velocity zone and linear alignment of seismicity along it in the subducted Pacific slab beneath Kanto, Japan: reactivation of subducted fracture zone? Geophys Res Lett 33:L16309. doi:10.1029/2006GL026773

Nakajima J, Hirose F, Hasegawa A (2009) Seismotectonics beneath the Tokyo metropolitan area, Japan: effect of slab-slab contact and overlap on seismicity. J Geophys Res 114:B08309. doi:10.1029/2008JB006101

Namegaya Y, Satake K, Shishikura M (2011) Fault models of the 1703 Genroku and 1923 Taisho Kanto earthquakes inferred from coastal movements in the southern Kanto area. Ann Rep Act Fault Paleoearthq Res 11:107-120 (in Japanese with English abstract)

Obana K, Kodaira S, Shinohara M, Hino R, Uehira K, Shiobara H, Nakahigashi K, Yamada T, Sugioka H, Ito A, Nakamura Y, Miura S, No T, Takahashi N (2013) Aftershocks near the updip end of the 2011 Tohoku-Oki earthquake. Earth Planet Sci Lett 382:111-116. doi:10.1016/j.epsl.2013.09.007

Okada Y, Kasahara K, Hori S, Obara K, Sekiguchi S, Fujiwara H, Yamamoto A (2004) Recent progress of seismic observation networks in Japan-Hi-net, F-net, K-NET and KiK-net. Earth Planets Space 56:XV-xxviii

Ozawa S, Miyazaki S, Hatanaka Y, Imakiire T, Kaidzu M, Murakami M (2003) Characteristic silent earthquakes in the eastern part of the Boso Peninsula, Central Japan. Geophys Res Lett. doi:10.1029/2002GL016665

Sagiya T (2004) Interplate coupling in the Kanto District, Central Japan, and the Boso Peninsula Silent Earthquake in May 1996. Pure appl Geophys 161:2327-2342. doi:10.1007/s00024-004-2566-6

Satake K, Fujii Y, Harada T, Namegawa Y (2013) Time and space distribution of coseismic slip of the 2011 Tohoku earthquake as inferred from Tsunami Waveform data. Bull Seism Soc Am 203(2B):1473-1492. doi:10.1785/0120120122

Sato T, Higuchi H, Miyauchi T, Endo K, Tsumura N, Ito T, Noda A, Matsu'ura M (2016) The source model and recurrence interval of Genroku-type Kanto earthquakes estimated from paleo-shoreline data. Earth Planets Space 68:17. doi:10.1186/s40623-016-0395-3 
Shinohara M, Yamada T, Nakahigashi K, Sakai S, Mochizuki K, Uehira K, Ito Y, Azuma R, Kaiho Y, No T, Shiobara H, Hino R, Murai Y, Yakiawra H, Sato T, Machida Y, Shinbo T, Isse T, Miyamachi H, Obana K, Takahashi N, Kodaira S, Kaneda Y, Hirata K, Yoshikawa S, Obara K, Iwasaki T, Hirata K (2011) Aftershock observation of the 2011 off the Pacific coast of Tohoku Earthquake by using ocean bottom seismometer network. Earth Planets Space 63:835-840. doi:10.5047/eps.2011.05.020

Shinohara M, Machida Y, Yamada T, Nakahigashi K, Shinbo T, Mochizuki K, Murai Y, Hino R, Ito Y, Sato T, Shiobara H, Uehira K, Yakiwara H, Obana K, Takahashi N, Kodaira S, Hirata K, Tsushima H, Iwasaki T (2012a) Precise aftershock distribution of the 2011 off the Pacific coast of Tohoku Earthquake revealed by an ocean-bottom seismometer network. Earth Planets Space 64:1137-1148. doi:10.5047/eps.2012.09.003

Shinohara M, Shiobara H, Suyehiro K (2012b) Site selection, preparation and installation of seismic stations. In: Bormann P (ed) New manual of seismological observatory practice 2 (NMSOP-2), Potsdam: Deutsches GeoForschungsZentrum GFZ, 7.5 Marine seismic observation of chapter 7. doi:10.2312/GFZ.NMSOP-2 ch7

Snoke JA (2003) FOCMEC: FOcal MEChanism determinations. In: Lee WHK, Kanamori H, Jennings PC, Kisslinger C (eds) International handbook of earthquake and engineering seismology. Academic Press, San Diego, Chapter 85.12

Toda S, Stein SR, Lin J (2011) Wide spread seismicity excitation throughout central Japan following the $2011 \mathrm{M}=0.9$ Tohoku earthquake and its interpretation by Coulomb stress transfer. Geophys Res Lett 38:L00G03. doi:10.1029/2011GL047834
Tsuru T, Park JO, Miura S, Kodaira S, Kido Y, Hayashi T (2002) Along-arc structural variation of the plate boundary at the Japan Trench margin: implication of interplate coupling. J Geophys Res 107:B12. doi:10.1029/2001JB001664 Uchida N, Nakajima J, Hasegawa A, Matsuzawa T (2009) What controls interplate coupling? Evidence for abrupt change in coupling across a border between two overlying plates in the NE Japan subduction zone. Earth Planet Sci Lett 283:111-121

Uchida N, Matsuzawa T, Nakajima J, Hasegawa A (2010) Subduction of a wedge-shaped Philippine Sea plate beneath Kanto, central Japan, estimated from converted waves and small repeating earthquakes. J Geophys Res 115:B07309. doi:10.1029/2009JB006797

Uchida N, Asano Y, Hasegawa A (2016) Acceleration of regional plate subduction beneath Kanto Japan, after the 2011 Tohoku-oki earthquake. Geophys Res Lett. doi:10.1002/2016GL070298

Ueno H, Hatakeyama S, Aketagawa T, Funasaki J, Hamada N (2002) Improvement of hypocenter determination procedures in the Japan Meteorological Agency. Q J Seismol 65:123-134 (in Japanese with English abstract)

Yagi Y, Fukahata Y (2011) Rupture process of the 2011 Tohoku-oki earthquake and absolute elastic strain release. Geophys Res Lett 38:L19307. doi:10.10 29/2011GL048701

\section{Submit your manuscript to a SpringerOpen ${ }^{\circ}$ journal and benefit from:}

- Convenient online submission

- Rigorous peer review

- Immediate publication on acceptance

- Open access: articles freely available online

- High visibility within the field

- Retaining the copyright to your article 